\title{
QUEEN'S
UNIVERSITY
BELFAST
}

\section{The problems of radiocarbon dating}

Blaauw, M., Christen, J. A., Guilderson, T. P., Reimer, P., \& Brown, T. A. (2005). The problems of radiocarbon dating. Science, 308(5728)(5728), 1551-1553. https://doi.org/10.1126/science.308.5728.1551

\section{Published in:}

Science

\section{Document Version:}

Publisher's PDF, also known as Version of record

\section{Queen's University Belfast - Research Portal:}

Link to publication record in Queen's University Belfast Research Portal

\section{General rights}

Copyright for the publications made accessible via the Queen's University Belfast Research Portal is retained by the author(s) and / or other copyright owners and it is a condition of accessing these publications that users recognise and abide by the legal requirements associated with these rights.

Take down policy

The Research Portal is Queen's institutional repository that provides access to Queen's research output. Every effort has been made to ensure that content in the Research Portal does not infringe any person's rights, or applicable UK laws. If you discover content in the Research Portal that you believe breaches copyright or violates any law, please contact openaccess@qub.ac.uk. 


\section{The Problems of Radiocarbon Dating}

IN THEIR PERSPECTIVE "THE BOON AND BANE of radiocarbon dating" (21 Jan., p. 362), T. P. Guilderson et al. raise some important issues in radiocarbon $\left({ }^{14} \mathrm{C}\right)$ dating. They discuss the problems of calibrating ${ }^{14} \mathrm{C}$ dates that fall within "age plateaus" of the ${ }^{14} \mathrm{C}$ calibration curve and conclude that "Far too often, the interpretations of leads, lags, or synchronicity of paleoclimate records are not fully supported by the radiocarbon chronology." Although we agree with their statements Guilderson et al. in our opinion, fail to highlight three vital points.

First, it is very rare nowadays to use one single date for inferring age models in archaeological and paleoclimate contexts. Robust Bayesian statistical techniques are available for handling sets of ${ }^{14} \mathrm{C}$ dates (1-4). Through careful and explicit use of statistics, the inherent uncertainties of isolated ${ }^{14} \mathrm{C}$ dates can be overcome, and the leads, lags, or synchronicity between different events can be properly identified.

Second, although they focus on the advantages of high-precision ${ }^{14} \mathrm{C}$ dates, Guilderson et al. do not mention that even a high-precision ${ }^{14} \mathrm{C}$ date is of very limited use if it is not accurate. Radiocarbon dates often need adjustments up to several ${ }^{14} \mathrm{C}$ "centuries" for age offsets that are only approximately known and that could vary with time [e.g., (5)]. Moreover, owing to contamination or handling errors, one in every 10 to $20{ }^{14} \mathrm{C}$ dates appears to be "outlying" (6). The outlier problem is far from trivial: In many studies, individual ${ }^{14} \mathrm{C}$ dates are removed manually and heuristically because they do not appear to fit the other data and the model applied (e.g., assumed chronological order of dates). Although perhaps not used widely enough, statistical techniques do exist to systematically handle both age offsets and outliers (1-4).

Finally, we note that Guilderson et al. work with $1 \sigma(68 \%)$ calibrated ranges. Although this could be a reasonable approach for data with a Gaussian probability distribution, this is not the case for

\section{Letters to the Editor}

Letters ( 300 words) discuss material published in Science in the previous 6 months or issues of general interest. They can be submitted through the Web (www.submit2science.org) or by regular mail (1200 New York Ave., NW, Washington, DC 20005, USA). Letters are not acknowledged upon receipt, nor are authors generally consulted before publication. Whether published in full or in part, letters are subject to editing for clarity and space.
${ }^{14} \mathrm{C}$ dates, where calibration nearly always gives rise to highly multimodal distributions. Reducing such distributions to mere $1 \sigma$ ranges can result in a considerable loss of information. We therefore argue that, at least for ${ }^{14} \mathrm{C}$ dates of centennial-scale studies, their probability distributions on the calendar scale should be provided.

MAARTEN BLAAUW* AND J. ANDRÉS CHRISTEN Centro de Investigación en Matemáticas, A.P. 402, 36000 Guanajuato, Gto., Mexico.

*To whom correspondence should be addressed. E-mail:blaauwm@cimat.mx

\section{References}

1. J. A. Christen, Appl. Stat. 43, 489 (1994).

2. C. E. Buck, W. G. Cavanagh, C. D. Litton, The Bayesian Approach to Interpreting Archaeological Data (Wiley, Chichester, UK, 1996).

3. C. E. Buck, J. A. Christen, G. N. James, Internet Archaeol. 7 (1999); see http://bcal.shef.ac.uk.

4. M. Blaauw, J. A. Christen, Appl. Stat., in press.

5. W. Broecker et al., Science 306, 1169 (2004).

6. E. M. Scott, Radiocarbon 45, 135 (2003).

\section{Response}

IN PRINCIPLE, WE AGREE WITH BLAAUW AND Christen's comments and provide the following clarifications. In our Perspective, we used variable ${ }^{14} \mathrm{C}$ dating precision $( \pm 40$ versus \pm 15 years) as a vehicle to promote the thoughtful consideration of achievable final dating accuracy for routine samples, including ${ }^{14} \mathrm{C}$-calendar calibration contributions. In hindsight, we perhaps should have stressed that the commonly used $68 \%$ (or 95\%) calibrated age ranges are derived from the calibration probability distributions, providing a condensed version of the information available from the source distributions. We used the simplification provided by the $68 \%$ calibrated age ranges for the purposes of estimating calibration uncertainty and hence achievable final dating accuracy over the thousands of years covered by the international calibration standard IntCa198. We agree with Blaauw and Christen that it would be desirable to present the probability distributions themselves when such information is of significance in particular studies.

Many studies (including marine-based calibration data) inherently or explicitly assume age offset constancy through time. This assumption almost certainly does not reflect reality going back thousands of years and through various climatic regimes. The synthetic calibrations that we performed are equivalent to ${ }^{14} \mathrm{C}$ dating well-preserved terrestrial macrofossils of known provenance and provide the "best case scenarios" for calibration purposes with respect to, for example, paleoclimate studies. In regard to the "outlier problem," full understanding of this issue requires in-depth consideration of the international intercomparison study that Blaauw and Christen cite. Such considerations suggest that simple statements like "one in every 10 to 
$20{ }^{14} \mathrm{C}$ dates appears to be "outlying"' do not reflect the complexity of the results obtained in the intercomparison study (1). The results indicate that $14 \%$ of the 92 laboratories participating in the study were responsible for more than $60 \%$ of the outliers.

We suggested the use of a priori information to improve chronologies, which can take advantage of Bayesian statistical techniques [e.g., adopted by Bcal (2), mexcal (3), and OxCal (4) calibration programs] to increase the accuracy of calibrated ages through exclusion of unlikely calibrated age results on individual dates. Notwithstanding Blaauw and Christen's emphasis on the application of statistical methods, and although it may be rare nowadays for a single date to be used for inferring age-models, all too often the chronology for a project is underfunded or appropriate material is lacking, resulting in a handful of dates spread too far apart to benefit from statistical modeling. In terms of overall reliability of the final chronologies, the selection of the proper quality materials for dating and a clear understanding of the association of those materials with the events of interest is of paramount importance - certainly much more important than any subsequent considerations of the optimal statistical methods to use in calibrating the ${ }^{14} \mathrm{C}$ dates.
Subsequent to publication of our Perspective, the international radiocarbon community has replaced IntCal98 with IntCal04 $(5,6)$. We strongly recommend that the scientific community take advantage of IntCal04 for all appropriate calibration work. TOM P. GUILDERSON, ${ }^{1,2}$ PAULA J. REIMER, ${ }^{1}$ TOM A. BROWN ${ }^{1}$

${ }^{1}$ LLNL Center for Accelerator Mass Spectrometry,
University of California, Livermore, CA 94550, USA. ${ }^{2}$ Institute of Marine Science and Department of Ocean Sciences, University of California, Santa Cruz, CA 95064, USA.

References

1. E. M. Scott, Radiocarbon 45, 135 (2003).

2. C. Buck, A. Christen, ISBA Bull. 7, 9 (2000).

3. J.A. Christen, C. D. Litton, J. Archaeol. Sci. 22,719 (1995).

4. C. B. Ramsey, Radiocarbon 37, 425 (1995)

5. P. J. Reimer et al., Radiocarbon 46, 1029 (2004)

6. K. A. Hughen et al., Radiocarbon 46, 1059 (2004).

\section{TECHNICAL COMMENT ABSTRACTS COMMENT ON "Thymic Origin of Intestinal $\alpha \beta$ T Cells Revealed by Fate Mapping of ROR $\gamma \mathbf{t}^{+}$Cells"}

Benedita Rocha

CD8 $\alpha \alpha$ intraepithelial gut T lymphocytes (IELs) differ from other T cells and have been proposed to differentiate from local precursors. Eberl and Littman (Reports, 9 July 2004, p. 248), however, argued that IELs expressing the $\alpha \beta \mathrm{T}$ cell receptor originate from $\mathrm{CD} 4^{+} \mathrm{CD} 8^{+}$thymocytes. We find their experiments inconclusive and their interpretations inconsistent with previously published data.

Full text at www.sciencemag.org/cgi/content/full/308/5728/1553a

\section{RESPONSE TO COMMENT ON "Thymic Origin of Intestinal $\alpha \beta$ T Cells Revealed by Fate Mapping of ROR $\gamma \mathbf{t}^{+}$Cells"}

\section{Gérard Eberl and Dan R. Littman}

We maintain that intraepithelial intestinal T lymphocytes expressing the $\alpha \beta$ T cell receptor are most likely derived from thymocytes and that cells previously identified as local precursors instead function as inducers of lymphoid follicles. In contrast to earlier studies involving cell transfers into athymic lymphopenic mice, our interpretations are based on nonperturbing genetic approaches.

Full text at www.sciencemag.org/cgi/content/full/308/5728/1553b 